\title{
Efficacy of Local Bioresources and Chemical Treatment against Quality Parameters of White Rot Inoculated Apple Fruits
}

\author{
Kishor Sharma* and Harender Raj \\ Department of Plant Pathology, Dr. Y.S. Parmar University of Horticulture and Forestry, \\ Nauni -173230, Solan, Himachal Pradesh, India \\ *Corresponding author
}

\section{A B S T R A C T}

\begin{tabular}{|l|}
\hline Ke y w or d s \\
Apple, \\
Quality parameters, \\
White rot, Storage. \\
\hline Article Info \\
\hline Accepted: \\
15 March 2017 \\
Available Online: \\
10 April 2017 \\
\hline \hline
\end{tabular}

\begin{abstract}
In vitro studies, aqueous extract of leaves of plants namely Karu (Roylea elegans), Artemisia (Artemisia roxburghiana), Neem (Azadirachta indica), Bana (Vitex negundo), Tulsi (Ocimum sanctum) and seed of Darek (Melia azedarach) were found effective in inhibiting the growth of the $B$. dothidea causing white rot in apple. These botanicals were mixed together and formulations were made in water (Botanical Formulations 1) and Cow urine (Botanical Formulations 2) on weight and volume basis. These two Botanical Formulations were evaluated against the disease along with chemical fungicide (Score) as fruit dip, dip of fruit wrappers and dip of fruit trays. Edible wax was also used in surface coating of the fruits. Skin coating of fruits in BF1 and BF2 was done by dipping the fruits in different treatment solutions for 30 minutes. From the present study it was concluded that different treatments have effects on quality parameters and shelf life of apple after 30 days of storage in comparison to untreated fruits as control. Different treatments i.e. fruit dip or impregnation of the packing material (trays or wrappers) with botanical formulations (BF1 and BF2) were significantly effective in reducing the physiological weight loss of fruits and retaining the fruit TSS, titratable acidity and firmness of apple fruit under storage. Fruits treated with $\mathrm{BF} 2$ were also found equally effective in retaining minimum fruit TSS $\left(11.98{ }^{\circ} \mathrm{Brix}\right)$, maximum titratable acidity $(0.28 \%)$ and fruit firmness (14.97 lbs/sq.inch) after 30 days of storage. Treatment with BF2 was found effective as edible wax coating in reducing the physiological weight loss by 3.61 and 3.33 per cent respectively, during storage.
\end{abstract}

\section{Introduction}

The apple is one of the most popular and healthy fruits. It is a deciduous variety of fruit grown extensively in temperate regions of the world and is generally believed to be originated from Central Asia and with time it was spread all over the world. Globally, it is the fourth most widely produced fruit in the world after banana, orange, and grapes (Ali et $a l ., 2004)$. According to the USDA, China is the topmost producer of apple with producing 43 million tons in the year 2015-16.

In India, apple is grown in an area of about 2, 89,000 hectare with total annual production of 28, 91,000 metric tonnes and national productivity of apple is 10.0 metric tonnes per hectare. It is commercially grown in the Himalayan regions including states of Jammu 
and Kashmir, Himachal Pradesh and Uttarakhand which together accounts for 99 per cent of the total production. The remaining 1 per cent is contributed by NorthEastern states viz. Arunachal Pradesh, Sikkim, Nagaland and Meghalaya (Anonymous, 2012).

Apple fruit is rich in certain nutrients and provide good source of energy due to their high content of carbohydrates $(13.9 \mathrm{~g} / 100 \mathrm{~g})$, fiber $(0.8 \mathrm{~g} / 100 \mathrm{~g})$, proteins $(0.4 \mathrm{~g} / 100 \mathrm{~g})$, lipid $(0.3 \mathrm{~g} / 100 \mathrm{~g})$, vitamin $\mathrm{C}(8 \mathrm{mg} / 100 \mathrm{~g})$, sodium $\quad(0.3 \mathrm{mg} / 100 \mathrm{~g}), \quad$ potassium $(145 \mathrm{mg} / 100 \mathrm{~g})$, calcium $(7 \mathrm{mg} / 100 \mathrm{~g})$, iron $(480 \mu \mathrm{g} / 100 \mathrm{~g})$, phosphorus (12 mg) and iodine $(2 \mu \mathrm{g} / 100 \mathrm{~m})$ (Hussain, 2001). They also have anti-oxidant effect mainly due to presence of polyphenols, such as quercetin, catechin and chlorogenic acid (Boyer and Liu, 2004; Kahkonen et al., 1999; Lu and Yeap, 2000). Apple consumption found to be also associated with reduction in cardiovascular, asthamatic and diabetic diseases (Sesso et al., 2003), (Knekt et al., 2002; Mueller et al., 2009). Apple is mostly consumed as fresh fruit, but due to its perishable nature, its quality deteriorates and cannot be stored for a long time. Quality of apple changes rapidly during storage that substantially affects the consumer acceptability (Vieira et al., 2009).

There are number of diseases which infect apple resulting in huge loss in yield. Postharvest losses to varied extent have been reported from different parts of the world. Anderson (1956) reported 80 to 90 per cent losses in apple fruit due to post-harvest diseases from United States. Jijakli and Lepoivre (2004) reported 5 to 25 per cent post-harvest losses in apple. Spadaro et al (2004) recorded 50 per cent losses due to post-harvest diseases such as grey mould (Botrytis cinerea) and blue mould (Penicillium expansum) on apple. McCollum (2002) concluded that fruit rot caused by fungal pathogens can lead to considerable post-harvest losses, varying with cultivar, area of production, and season. Ilyas et al., (2007) reported ninety fungal species associated with post-harvest decay in apple during storage. The major post-harvest pathogens of pome fruits are Penicillium expansum, Botrytis cinerea and Monilinia fructigena and other common fungal species isolated from rotten pome fruits are Colletotrichum, Mucor, Rhizopus, Alternaria, Botryosphaeria, Fusarium, Neofabraea (Konstantinou et al.,, 2011; Snowdon, 1990).

Ismail et al., (2006) reported that chemical and physical characteristics of the fruits influenced their mechanical and rheological properties, which in turn can be indicators of firmness and ultimately of quality. Postharvest treatment offers a pesticide free method to kill or weaken plant pathogens, control insect infestations and maintain fruit storage quality (Barkai-Golan and Phillips, 1991; Shao et al., 2007). From the last few years, the use of various chemicals, waxing material and fungicide are becoming popular among growers in order to enhance the shelf life of fruits. However, the use of these substances has their own limitations, as some of them are believed to be ecologically unsafe and economically not viable besides leaving their residue on the fruit surface, which may have the direct hazardous effect on human health. Additionally, they may be associated with the changes in physiochemical characteristics of the fruits. In order to overcome these shortcomings, there is urgent need of substances which are of biological origin with fungicidal, insecticidal properties (Dhaliwal and Arora, 1996). Therefore, present study was undertaken with the objective to study the effect of different bioresources such as cow urine-plant extract based formulation, aqueous-plant extract formulation and edible wax treatment on physiochemical characteristics of the apple fruit during storage. 


\section{Materials and Methods}

Freshly harvested fruits of Golden Delicious variety were procured from the market and these fruits were spread out on the working table of the laboratory so that fruits of uniform shape, size and maturity were selected. These fruits were sorted out to discard any immature, over-ripe, bruised undersized or diseased fruit. Rest of the fruits were used for the management and other studies in the objectives. In each treatment, 45 fruits of uniform size were selected randomly. The whole experiment was conducted in two consecutive year 2012 and 2013, respectively.

\section{Preparation of botanical formulations}

Six effective plant extracts, which inhibited maximum radial growth of the white rot fungus (B. dothidea) under in vitro conditions were combined and evaluated in two combinations of Botanical Formulations 1 (BF1) and Botanical Formulations 2 (BF2) in different treatments. In Botanical Formulation (BF1), equal quantity (200 g) of sixty days old freshly harvested leaves of Karu (Roylea elegans Wall.), Artemisia (Artemisia roxburghiana Wall.), Neem (Azadirachta indica L.), Bana (Vitex negundo Linn.), Tulsi (Ocimum sanctum L.) and $200 \mathrm{~g}$ of mature seeds of Darek (Melia azedarach L.) were taken. These leaves and seeds were washed in the running tap water and then with distilled water. Then, the paste of all these ingredients was made in a mixer and grinder. Then, equal quantity of distilled water $(200 \times 6=1200$ $\mathrm{ml}$ ) was added to this paste of leaves and seeds of six plants on weight and volume basis (w/v). In Botanical Formulation 2 (BF2), equal quantity (200 g) of sixty days old freshly harvested leaves of Karu (Roylea elegans Wall.), Artemisia (Artemisia roxburghiana Wall.), Neem (Azadirachta indica L.), Bana (Vitex negundo Linn.), Tulsi (Ocimum sanctum L.) and $200 \mathrm{~g}$ of mature seeds of Darek (Melia azedarach L.) were taken. These leaves and seeds were washed in the running tap water and then with distilled water. Then the pastes of all these ingredients were made in mixer grinder by adding little quantity of fresh cow urine of Jersey cow. Then equal quantity of cow urine $(200 \times 6=$ $1200 \mathrm{ml}$ ) was added to this paste of leaves and seeds of six plants on weight and volume basis (w/v). Thus, while BF1 is water based formulation, BF2 is cow urine based formulation. Then efficacy of Botanical Formulations (BF1 and BF2) was compared with other treatments of effective fungicide (Score) and edible wax (carnauba wax) as fruit dip, dip of fruit wrappers and dip of fruit trays. Skin coating of fruits in BF1 and BF2 was done by dipping the fruits in different treatment solutions for 30 minutes. Fruits were dried after the treatment in the laboratory by spreading on working tables before packing in the trays. Fruit wrappers and trays were impregnated with botanical formulations and the test fungicide treatment for the protection of apple fruits. Daily newspaper sheets of $(52 \times 33 \mathrm{~cm})$ dimension were used as fruit wrappers. To prepare the impregnated wrappers of $\mathrm{BF} 1$ and $\mathrm{BF} 2$ five sheets of newspaper were slowly poured with the solution $(150$ to $200 \mathrm{ml})$ of the different treatment separately in a way so that the sheets (wrappers) were drenched with the solution and that solution also do not spill out from set of five sheets. Uniform soaking of solution of each treatment was secured by spreading the solution smoothly over the sheets. The newspaper sheets were air dried in shade and sheets were then cut and divided in to wraps of uniform size measuring $25 \mathrm{~cm}^{2}$ in dimension. Similarly, fruit trays were also impregnated by dipping of these trays in different treatment solutions (BF1 and BF2) for 30 minutes. Trays were air dried after the treatment under shade in the laboratory before packing the fruits in the trays. Sterilized distilled water was taken as control for skin 
coating of fruits. Observations regarding efficacy of these treatments on physiochemical parameters of fruits against white rot fungus inoculated fruits were recorded after 10, 20 and 30 days in storage at $25 \pm 3{ }^{0} \mathrm{C}$.

\section{Different treatments used during} physiochemical parameters study of apple fruits during storage are following-

T1: [Apple treated + Tray untreated (BF1)]

T2: [Apple untreated + Tray treated (BF1)]

T3: [Apple treated + Tray untreated (BF2)]

T4: [Apple untreated + Tray treated (BF2)]

T5: [Apple treated + Tray untreated (Fungicide)]

T6: [Apple untreated + Tray treated (Fungicide)]

T7: Apple treatment with edible wax

T8: Treatment of wrappers with BF1

T9: Treatment of wrappers with BF2

T10: Treatment of wrappers with fungicide

T11: Control

\section{Fruit qualitative characters}

Fruit qualitative analysis in terms of Total Soluble Solids (TSS) and titratable acidity, fruit firmness and physical weight loss were assayed from diseased and healthy fruits in each treatment at interval of 10, 20 and 30 days at $25 \pm 3^{0} \mathrm{C}$ storage.

\section{Total soluble solids ( ${ }^{0}$ Brix)}

The total soluble solids (TSS) content of the fruit sample were determined with the help of an 'Erma' hand refractometer. Total soluble solid were determined by calibrating with distilled water followed by dropping 1-2 drops of drop of the juice squeezed from the sample was placed on the prism and viewed through the eye piece and expressed as ${ }^{\circ}$ Brix. Five fruits were taken from each treatment for recording this observation. TSS was determined and results were expressed as per cent of total soluble solids ( ${ }^{\mathbf{0}} \mathrm{Brix}$ ).

\section{Titratable acidity}

Twenty five gram of fruit pulp was thoroughly homogenized with distilled water in a waring blender and the volume was made upto $250 \mathrm{ml}$. Then, the homogenized mixture was filtered through Whatman No.1 filter paper. Then $10 \mathrm{ml}$ sample from the filtrate was titrated against $0.1 \mathrm{~N} \mathrm{NaOH}$ solution using phenolphthalein as indicator in each treatment. The end point was noted with change in colour to pink. The total titratable acidity was calculated in term of malic acid on basis of $1 \mathrm{ml}$ of $0.1 \mathrm{~N} \mathrm{NaOH}$ being equivalent to $0.0067 \mathrm{~g}$ anhydrous malic acid. The results were expressed as per cent flesh weight of fruit pulp.

\section{Titratable Acidity $(\%)$ Titre X normality of alkali $X$ volume made up X equivalentwt. of acid \\ volume of sample taken for estmation $X$ wt. or volume of sample takent $X 1000$ $\times 100$}

\section{Fruit firmness}

The fruit firmness of apple fruits was estimated with the help of a penetrometer (Effigi penetrometer (FT-327) in all the management studies to ascertain the quality of fruits in different treatments. The skin of the fruit was removed using slicers to a $1-\mathrm{mm}$ cutting depth and flesh firmness was then measured with a penetrometer equipped with an 11-mm diameter plunger tip and the observations were noted down in lbs/sq. inch.

\section{Effect on Physiological Weight Loss (PWL)}

In the experiment studies, 10 representative fruits from each replication were weighed in the beginning using digital balance (Narang Scientific Works Pvt. Ltd.) and then same marked fruits were weighed at an interval of 
10, 20 and 30 days during the period of the experiment in each treatment. The loss in weight at each interval during storage was recorded.

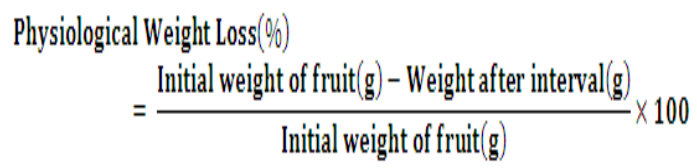

\section{Results and Discussion}

\section{Effect of post-harvest treatments on Total Soluble Solids (TSS)}

Post-harvest diseases adversely affect the quality of the fruits and hence effect of different treatments was observed on the Total Soluble Solids (TSS) content of the treated apple fruits at different time intervals in storage (Table 1). Pooled average data of two years indicated that TSS content of the fruits increased with the advancement of storage period. After 30 days of storage, treatment T5 in which fruits were treated with fungicide (Score) had minimum TSS of 11.93 ${ }^{0}$ Brix. Fruits which were treated with BF2 (T3) were next in efficacy with TSS of 11.98 ${ }^{0}$ Brix. Treatments $\mathrm{T} 1$ and $\mathrm{T} 7$ were proved next effective to reduce the fruit rotting and retaining TSS to $12.33{ }^{0} \mathrm{Brix}$ and $12.35^{\circ} \mathrm{Brix}$, respectively. After 30 days of storage TSS content of rotten fruits in control (untreated) were declined to $8.82{ }^{0} \mathrm{Brix}$. Overall pooled data of the two years indicate that minimum rotting was recorded in treatment $\mathrm{T} 5$ with TSS (11.18 ${ }^{0}$ Brix) which was followed by T3 with TSS $11.25{ }^{0}$ Brix. Maximum rotting was recorded in control with TSS value 11.35 ${ }^{0}$ Brix. Total soluble solids (TSS) content of the fruits have been reported to increase during storage (Rivera, 2005). The increase in TSS during rotting by pathogens could be attributed to the breakdown of starch into sugars or the hydrolysis of cell wall polysaccharides (Ben and Gaweda, 1985; Beaudry et al., 1989). In earlier studies, Kim et al., (1997) also reported that at lower incidence of white rot $(4.2 \%)$ TSS content of the apple fruits was $9.6{ }^{0} \mathrm{Brix}$, but as the incidence of rot increased to 14.2 per cent, the TSS of the fruits also increased to $10.1^{0} \mathrm{Brix}$. Tzortzakis (2007) reported that treatment of strawberry fruit with cinnamon (Cinnamomum zeylanicum) and eucalyptus (Eucalyptus globulus) vapours increased the fruit TSS during storage. Fruit coating of apple with neem oil has been reported to provide better retention of physico-chemical characteristics of fruits including firmness, total soluble solids, and titratable acidity of fruit (Chauhan et al., 2008; Wijewardane and Guleria, 2009).

\section{Effect of post-harvest treatments on Titratable Acidity (TA)}

Titratable acidity of fruits was decreased significantly under all the treatments (Table $2)$. Pooled average titratable acidity was found to be maximum $(0.28 \%)$ in the treatments T5 and T3 after 30 days of storage in which fruits were treated with fungicide (Score) and BF2. Titratable acidity values of fruits treated with both these treatments (BF2 and fungicide) were statistically at par with each other. It is followed by the treatments T1 and T7, in which Fruits treated with BF1 and edible wax (T7) had titratable acidity of 0.27 per cent each. After 30 days of storage, minimum mean titratable acidity was recorded in control which was 0.21 per cent. Over all pooled data of two years indicate that mean titratable acidity was maximum $(0.30 \%)$ in treatment $\mathrm{T} 5$ followed by treatments $\mathrm{T} 1$ and T3 with mean titratable acidity of 0.29 per cent each. Minimum titratable acidity was recorded in control which was 0.24 per cent. Titratable acidity of the fruits has been reported to gradually decline with the advancement of rotting of fruits in storage (Soliva and Martin, 2003). Different treatments appreciably improved the titratable 
acidity of fruits. Minimum reduction in titratable acidity 15.2 per cent (from $0.33 \%$ at beginning to $0.28 \%$ ) was recorded in the fruits treated with Score and BF2. Impregnation of trays in BF2 was also found effective with reduction of 21.2 per cent in titratable acidity in comparison to the fruits at time of storage, although, BF1 was found less effective than BF2 but packing of fruits in impregnated trays with BF1 resulted in 24.2 per cent reduction in titratable acidity after 30 days of storage. Maximum reduction in titratable acidity 36.4 per cent was recorded in control after 30 days of storage. Similarly, Wijewardane and Guleria (2009) also reported maximum titratable acidity $(0.30 \%)$ in apple fruits treated with neem oil. Shinde et al., (2009) also reported fruit dip treatment with neem oil (10\%) was highly effective in retaining maximum titratable acidity of mango fruits in storage. Ergun and Satici (2012) reported that higher concentration of Aloe vera gel delayed titratable acidity in Granny Smith variety of apple.

\section{Effect of post-harvest treatments on Fruit pressure (Firmness)}

Fruit firmness decreased under all treatments as the storage period progressed (Table 3). Among different treatments, maximum mean firmness (15.10 lbs/sq.inch) was observed in T5 where the fruits treated with fungicide (Score). Treatment T3 with fruit firmness of $14.97 \mathrm{lbs} / \mathrm{sq}$. inch was next in efficacy in which fruits were treated with BF2. Fruits treated with edible wax had $14.43 \mathrm{lbs} / \mathrm{sq}$.inch fruit firmness. On other hand, minimum mean fruit firmness was recorded in control fruits (8.52 lbs/sq. inch).

Infection of white rot on fruits drastically reduced the firmness of fruits from $16.54 \mathrm{lbs} /$ sq. inch at the time of the storage to $5.60 \mathrm{lbs} /$ sq. inch after 30 days of storage in control. However, different treatments appreciably improved the fruit firmness. Minimum loss in fruit firmness 12.39 per cent (from $16.54 \mathrm{lbs} /$ sq. inch in the beginning to $14.53 \mathrm{lbs} / \mathrm{sq}$. inch) was recorded in the fruits treated with Score followed by 12.40 per cent loss in firmness of fruits treated with BF2. In fruits treated with edible wax, loss in fruit firmness was 17.71 per cent. Fruits treated with BF1 had 17.84 per cent loss in firmness as compared to control after 30 days of storage. Impregnation of trays with $\mathrm{BF} 2$ reduced the firmness by 19.5 per cent. Although BF1 was less effective than BF2, but packing of fruits in impregnated trays with $\mathrm{BF} 1$ result in $21.6 \%$ reduction in fruit firmness in comparison to control after 30 days.

In earlier studies, Raj and Tomar (2013) reported that fruit dip in botanical formulation with cow urine was equally effective in retaining firmness of fruits during storage. Combination of chitosan and aqueous extracts of leaves of custard apple, leaves and seeds of papaya has inhibitory effect on the development of anthracnose (Colletotrichum gloeosporioides) in papaya and it also resulted in retaining the fruit firmness as rotting progresses (Bautista-Banos et al., 2003).

\section{Effect of post-harvest treatments on Physiological Loss in Weight (PLW)}

Minimum mean physiological loss in weight $(4.52 \%)$ was recorded in treatment $\mathrm{T} 7$ where fruits were treated with edible wax (Table 4). It was followed by treatment $\mathrm{T} 5$ with physiological loss in weight of 4.77 per cent containing the fruits which were treated with fungicide.

Fruits treated with (BF2) T3 and BF1 separately reduced physiological loss in weight to 4.87 and 5.11 per cent, respectively and both were found statistically at par. 
Table.1 Effect of different treatments on TSS (0Brix) of apple fruits at different duration in storage

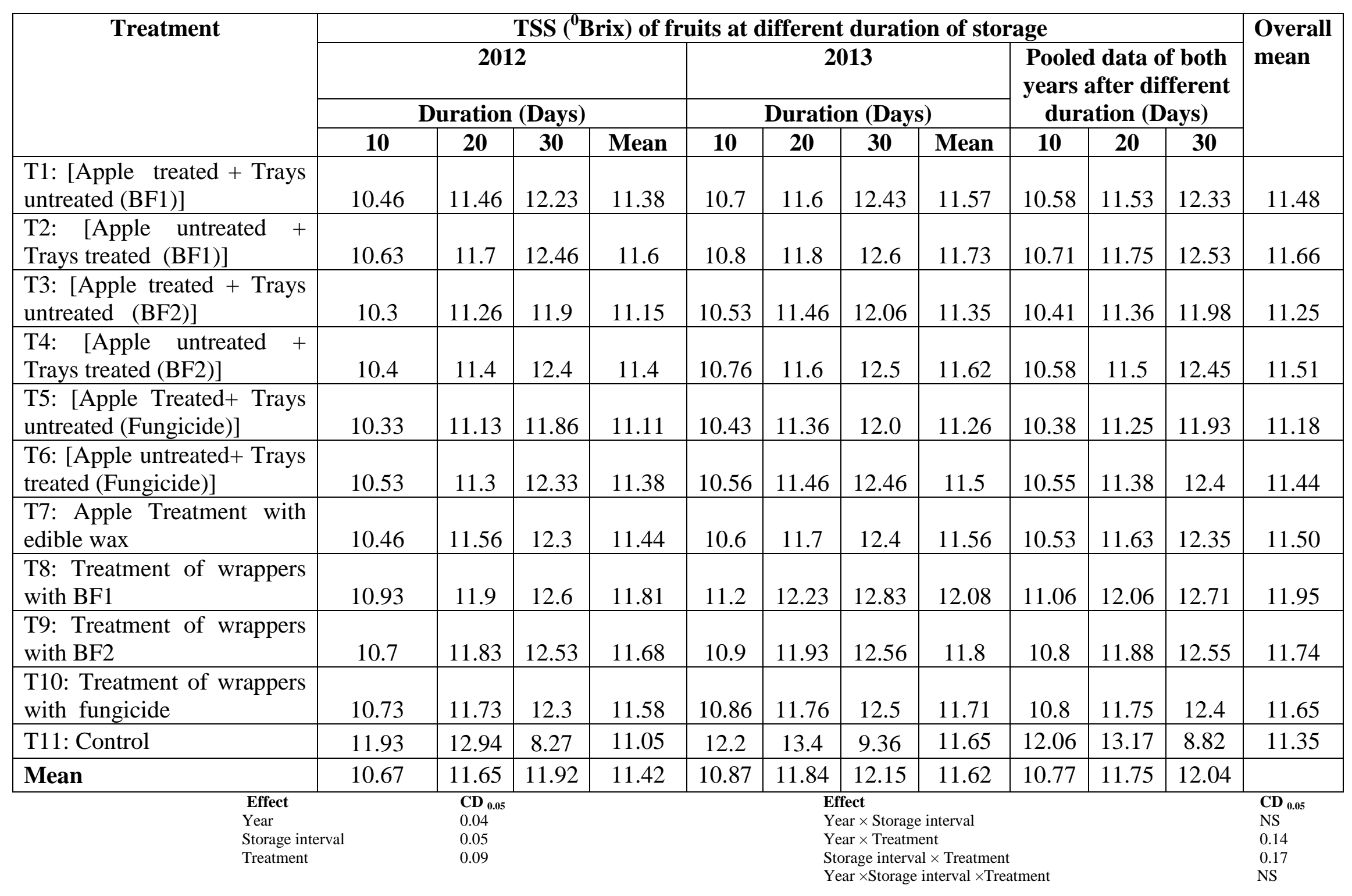


Table.2 Effect of different treatments on titratable acidity (\%) of apple fruits at different durations in storage

\begin{tabular}{|c|c|c|c|c|c|c|c|c|c|c|c|c|}
\hline \multirow{4}{*}{ Treatment } & \multicolumn{11}{|c|}{ Titratable acidity (\%) of fruits at different durations in storage } & \multirow{4}{*}{$\begin{array}{l}\text { Over } \\
\text { all } \\
\text { Mean }\end{array}$} \\
\hline & \multirow{2}{*}{\multicolumn{4}{|c|}{$\begin{array}{c}2012 . \\
\text { Duration (Days) }\end{array}$}} & \multirow{2}{*}{\multicolumn{4}{|c|}{$\begin{array}{c}2013 \\
\text { Duration (Days) }\end{array}$}} & \multirow{2}{*}{\multicolumn{3}{|c|}{$\begin{array}{c}\text { Pooled data of both } \\
\text { years after different } \\
\text { duration (Days) }\end{array}$}} & \\
\hline & & & & & & & & & & & & \\
\hline & 10 & 20 & 30 & Mean & 10 & 20 & 30 & Mean & 10 & 20 & 30 & \\
\hline $\begin{array}{l}\text { T1: [Apple treated }+ \text { Trays untreated } \\
(\mathrm{BF} 1)]\end{array}$ & 0.29 & 0.27 & 0.26 & 0.28 & 0.31 & 0.29 & 0.28 & 0.29 & 0.30 & 0.28 & 0.27 & 0.29 \\
\hline $\begin{array}{l}\text { T2: [Apple untreated + Trays treated } \\
(\mathrm{BF} 1)]\end{array}$ & 0.27 & 0.26 & 0.24 & 0.26 & 0.29 & 0.28 & 0.26 & 0.28 & 0.28 & 0.27 & 0.25 & 0.27 \\
\hline $\begin{array}{l}\text { T3: [Apple treated }+ \text { Trays untreated } \\
(\mathrm{BF} 2)]\end{array}$ & 0.30 & 0.29 & 0.27 & 0.28 & 0.32 & 0.31 & 0.29 & 0.30 & 0.31 & 0.30 & 0.28 & 0.29 \\
\hline $\begin{array}{c}\text { T4: [Apple untreated + Trays treated } \\
(\mathrm{BF} 2)]\end{array}$ & 0.28 & 0.26 & 0.25 & 0.27 & 0.30 & 0.28 & 0.27 & 0.28 & 0.29 & 0.27 & 0.26 & 0.27 \\
\hline $\begin{array}{c}\text { T5: [Apple Treated+ Trays untreated } \\
\text { (Fungicide)] }\end{array}$ & 0.30 & 0.29 & 0.28 & 0.29 & 0.32 & 0.31 & 0.29 & 0.31 & 0.31 & 0.30 & 0.28 & 0.30 \\
\hline $\begin{array}{c}\text { T6: [Apple untreated+ Trays treated } \\
\text { (Fungicide)] }\end{array}$ & 0.29 & 0.27 & 0.26 & 0.27 & 0.30 & 0.29 & 0.27 & 0.28 & 0.29 & 0.28 & 0.26 & 0.28 \\
\hline T7: Apple Treatment with edible wax & 0.28 & 0.27 & 0.26 & 0.27 & 0.30 & 0.29 & 0.28 & 0.29 & 0.29 & 0.28 & 0.27 & 0.28 \\
\hline T8: Treatment of wrappers with BF1 & 0.27 & 0.24 & 0.22 & 0.25 & 0.30 & 0.26 & 0.25 & 0.27 & 0.29 & 0.25 & 0.24 & 0.26 \\
\hline T9: Treatment of wrappers with BF2 & 0.27 & 0.25 & 0.23 & 0.25 & 0.29 & 0.27 & 0.26 & 0.27 & 0.28 & 0.26 & 0.25 & 0.26 \\
\hline $\begin{array}{l}\text { T10: Treatment of wrappers with } \\
\text { fungicide }\end{array}$ & 0.28 & 0.26 & 0.24 & 0.26 & 0.30 & 0.27 & 0.26 & 0.28 & 0.29 & 0.26 & 0.25 & 0.27 \\
\hline T11: Control & 0.25 & 0.23 & 0.24 & 0.23 & 0.28 & 0.24 & 0.22 & 0.24 & 0.27 & 0.23 & 0.21 & 0.24 \\
\hline Mean & 0.28 & 0.26 & 0.25 & 0.26 & 0.30 & 0.28 & 0.26 & 0.28 & 0.29 & 0.27 & 0.26 & \\
\hline $\begin{array}{l}\text { Effect } \\
\text { Year } \\
\text { Storage interval } \\
\text { Treatment }\end{array}$ & & & & & & & $\begin{array}{l}\text { ct } \\
\text { X Storag } \\
\text { X Treatn } \\
\text { age interv } \\
\text { X Storag }\end{array}$ & $\begin{array}{l}\text { erval } \\
\text { Treatment } \\
\text { erval X Tre: }\end{array}$ & & $\begin{array}{l}\mathrm{C} \\
\mathrm{N} \\
\mathrm{N} \\
0 \\
\mathrm{~N}\end{array}$ & & \\
\hline
\end{tabular}


Table.3 Effect of different treatments on fruit firmness (lbs/sq.inch) of apple fruits at different durations

\begin{tabular}{|c|c|c|c|c|c|c|c|c|c|c|c|c|}
\hline \multirow[t]{4}{*}{ Treatment } & \multicolumn{11}{|c|}{ Pressure (lbs/sq.inch) at different durations in storage } & \multirow{4}{*}{$\begin{array}{l}\text { Overall } \\
\text { mean }\end{array}$} \\
\hline & \multirow{2}{*}{\multicolumn{4}{|c|}{$\begin{array}{c}2012 \\
\text { Duration (Days) }\end{array}$}} & \multirow{2}{*}{\multicolumn{4}{|c|}{\begin{tabular}{|c|}
2013 \\
Duration (Days)
\end{tabular}}} & \multirow{2}{*}{\multicolumn{3}{|c|}{\begin{tabular}{|} 
Pooled data of both \\
years after different \\
duration (Days)
\end{tabular}}} & \\
\hline & & & & & & & & & & & & \\
\hline & 10 & 20 & 30 & Mean & 10 & 20 & 30 & $\begin{array}{c}\text { Mea } \\
\text { n }\end{array}$ & 10 & 20 & 30 & \\
\hline $\begin{array}{l}\text { T1: [Apple } \text { treated }+ \text { Trays } \\
\text { untreated } \\
(\mathrm{BF} 1)]\end{array}$ & 15.55 & 13.88 & 13.69 & 14.37 & 15.3 & 13.68 & 13.49 & 14.15 & 15.43 & 13.78 & 13.59 & 14.26 \\
\hline $\begin{array}{l}\text { T2: [Apple untreated }+ \text { Trays } \\
\text { treated } \\
(\mathrm{BF} 1)]\end{array}$ & 15.31 & 13.73 & 13.08 & 14.04 & 15.11 & 13.54 & 12.87 & 13.84 & 15.21 & 13.64 & 12.97 & 13.94 \\
\hline $\begin{array}{l}\text { T3: [Apple treated }+ \text { Trays } \\
\text { untreated }(\mathrm{BF} 2)]\end{array}$ & 15.67 & 14.94 & 14.59 & 15.07 & 15.47 & 14.75 & 14.39 & 14.87 & 15.57 & 14.84 & 14.49 & 14.97 \\
\hline $\begin{array}{l}\text { T4: [Apple untreated }+ \text { Trays } \\
\text { treated (BF2)] }\end{array}$ & 15.42 & 13.97 & 13.42 & 14.27 & 15.19 & 13.79 & 13.19 & 14.06 & 15.30 & 13.88 & 13.31 & 14.16 \\
\hline $\begin{array}{l}\text { T5: [Apple Treated+ } \\
\text { untreated (Fungicide)] }\end{array}$ & 15.76 & 15.22 & 14.65 & 15.21 & 15.58 & 15.01 & 14.4 & 14.99 & 15.67 & 15.11 & 14.53 & 15.10 \\
\hline $\begin{array}{l}\text { T6: [Apple untreated+ Trays treated } \\
\text { (Fungicide)] }\end{array}$ & 15.47 & 14.04 & 13.75 & 14.42 & 15.34 & 13.85 & 13.53 & 14.24 & 15.41 & 13.94 & 13.64 & 14.33 \\
\hline $\begin{array}{l}\text { T7: Apple Treatment with edible } \\
\text { wax }\end{array}$ & 15.50 & 14.38 & 13.71 & 14.53 & 15.3 & 14.18 & 13.51 & 14.33 & 15.4 & 14.28 & 13.61 & 14.43 \\
\hline $\begin{array}{l}\text { T8: Treatment of wrappers with } \\
\text { BF1 }\end{array}$ & 15.04 & 13.64 & 12.9 & 13.86 & 14.84 & 13.45 & 12.70 & 13.66 & 14.94 & 13.54 & 12.80 & 13.76 \\
\hline $\begin{array}{l}\text { T9: Treatment of wrappers with } \\
\text { BF2 }\end{array}$ & 15.10 & 13.79 & 13.29 & 14.06 & 14.90 & 13.59 & 13.06 & 13.85 & 15.00 & 13.69 & 13.17 & 13.97 \\
\hline $\begin{array}{l}\text { T10: Treatment of wrappers with } \\
\text { fungicide }\end{array}$ & 15.46 & 14.29 & 13.42 & 14.39 & 15.32 & 14.09 & 13.24 & 14.22 & 15.39 & 14.19 & 13.33 & 14.30 \\
\hline T11: control & 11.71 & 8.41 & 5.7 & 8.61 & 11.54 & 8.22 & 5.50 & 8.42 & 11.63 & 8.32 & 5.60 & 8.52 \\
\hline Mean & 15.09 & 13.66 & 12.92 & 13.89 & 14.9 & 13.47 & 12.71 & 13.69 & 14.99 & 13.57 & 12.82 & \\
\hline $\begin{array}{l}\text { CD }_{0.05} \\
\text { Year } \\
\text { Storage interval } \\
\text { Treatment }\end{array}$ & & $\begin{array}{l}0.01 \\
0.01 \\
0.01\end{array}$ & & & $\begin{array}{l}\text { CD } 0.05 \\
\text { Year X S } \\
\text { Year X T } \\
\text { Storage ir } \\
\text { Year X Sto }\end{array}$ & $\begin{array}{l}\text { orage inte } \\
\text { eatment } \\
\text { terval X T } \\
\text { rage inter }\end{array}$ & $\begin{array}{l}\text { val } \\
\text { reatment } \\
\text { al X Trea }\end{array}$ & & & & & \\
\hline
\end{tabular}


Table.4 Effect of different treatment on Physiological Weight Loss (\%) of the apple fruits at different durations in storage

\begin{tabular}{|c|c|c|c|c|c|c|c|c|c|c|c|c|}
\hline \multirow[t]{3}{*}{ Treatment } & \multicolumn{11}{|c|}{ Physiological weight loss (\%) } & \multirow{3}{*}{$\begin{array}{l}\text { Overall } \\
\text { mean }\end{array}$} \\
\hline & \multicolumn{4}{|c|}{2012} & \multicolumn{4}{|c|}{2013} & \multicolumn{3}{|c|}{$\begin{array}{c}\text { Pooled data of both years } \\
\text { after different duration } \\
\text { (Days) }\end{array}$} & \\
\hline & 10 & 20 & 30 & Mean & 10 & 20 & 30 & Mean & 10 & 20 & 30 & \\
\hline $\begin{array}{l}\text { T1: }[\text { Apple } \text { treated }+ \text { Trays } \\
\text { untreated }(\mathrm{BF} 1)]\end{array}$ & $\begin{array}{c}2.15 \\
(1.77) \\
\end{array}$ & $\begin{array}{c}4.00 \\
(2.23) \\
\end{array}$ & $\begin{array}{c}5.05 \\
(2.46) \\
\end{array}$ & $\begin{array}{c}5.11 \\
(2.47) \\
\end{array}$ & $\begin{array}{c}2.41 \\
(1.84)\end{array}$ & $\begin{array}{c}4.12 \\
(2.26)\end{array}$ & $\begin{array}{c}5.17 \\
(2.48) \\
\end{array}$ & $\begin{array}{c}3.90 \\
(2.19) \\
\end{array}$ & $\begin{array}{c}2.28 \\
(1.81)\end{array}$ & $\begin{array}{c}4.06 \\
(2.25) \\
\end{array}$ & $\begin{array}{c}5.11 \\
(2.47) \\
\end{array}$ & $\begin{array}{c}3.81 \\
(2.17) \\
\end{array}$ \\
\hline $\begin{array}{l}\text { T2: [Apple untreated + Trays treated } \\
(\mathrm{BF} 1)]\end{array}$ & $\begin{array}{c}2.38 \\
(1.84)\end{array}$ & $\begin{array}{c}4.20 \\
(2.28) \\
\end{array}$ & $\begin{array}{c}5.80 \\
(2.60) \\
\end{array}$ & $\begin{array}{c}5.91 \\
(2.63) \\
\end{array}$ & $\begin{array}{c}2.63 \\
(1.90)\end{array}$ & $\begin{array}{c}4.40 \\
(2.32)\end{array}$ & $\begin{array}{c}6.03 \\
(2.65) \\
\end{array}$ & $\begin{array}{c}4.35 \\
(2.29) \\
\end{array}$ & $\begin{array}{c}2.51 \\
(1.87) \\
\end{array}$ & $\begin{array}{c}4.30 \\
(2.30) \\
\end{array}$ & $\begin{array}{c}5.90 \\
(2.62) \\
\end{array}$ & $\begin{array}{c}4.24 \\
(2.26) \\
\end{array}$ \\
\hline $\begin{array}{l}\text { T3: [Apple treated + Trays untreated } \\
(\mathrm{BF} 2)]\end{array}$ & $\begin{array}{c}2.03 \\
(1.74)\end{array}$ & $\begin{array}{c}3.53 \\
(2.12) \\
\end{array}$ & $\begin{array}{c}4.84 \\
(2.41)\end{array}$ & $\begin{array}{c}4.87 \\
(2.42) \\
\end{array}$ & $\begin{array}{c}2.30 \\
(1.81)\end{array}$ & $\begin{array}{c}4.05 \\
(2.24)\end{array}$ & $\begin{array}{c}4.91 \\
(2.43)\end{array}$ & $\begin{array}{c}3.75 \\
(2.16) \\
\end{array}$ & $\begin{array}{c}2.16 \\
(1.77) \\
\end{array}$ & $\begin{array}{c}3.79 \\
(2.18) \\
\end{array}$ & $\begin{array}{c}4.87 \\
(2.42) \\
\end{array}$ & $\begin{array}{c}3.61 \\
(2.13) \\
\end{array}$ \\
\hline $\begin{array}{l}\text { T4: [Apple untreated + Trays treated } \\
\text { (BF2)] }\end{array}$ & $\begin{array}{c}2.34 \\
(1.82)\end{array}$ & $\begin{array}{c}4.15 \\
(2.27) \\
\end{array}$ & $\begin{array}{c}5.77 \\
(2.60) \\
\end{array}$ & $\begin{array}{c}5.88 \\
(2.62) \\
\end{array}$ & $\begin{array}{c}2.59 \\
(1.89)\end{array}$ & $\begin{array}{c}4.33 \\
(2.30) \\
\end{array}$ & $\begin{array}{r}5.99 \\
(2.64) \\
\end{array}$ & $\begin{array}{c}4.30 \\
(2.28) \\
\end{array}$ & $\begin{array}{c}2.46 \\
(1.86) \\
\end{array}$ & $\begin{array}{c}4.24 \\
(2.29) \\
\end{array}$ & $\begin{array}{c}5.88 \\
(2.62) \\
\end{array}$ & $\begin{array}{c}4.19 \\
(2.25) \\
\end{array}$ \\
\hline $\begin{array}{l}\text { T5: [Apple Treated+ Trays untreated } \\
\text { (Fungicide)] }\end{array}$ & $\begin{array}{c}2.03 \\
(1.74)\end{array}$ & $\begin{array}{c}3.44 \\
(2.10)\end{array}$ & $\begin{array}{c}4.70 \\
(2.38)\end{array}$ & $\begin{array}{l}4.77 \\
(2.40)\end{array}$ & $\begin{array}{c}2.25 \\
(1.80)\end{array}$ & $\begin{array}{c}4.03 \\
(2.24)\end{array}$ & $\begin{array}{c}4.83 \\
(2.41)\end{array}$ & $\begin{array}{c}3.70 \\
(2.15)\end{array}$ & $\begin{array}{c}2.14 \\
(1.77) \\
\end{array}$ & $\begin{array}{c}3.73 \\
(2.17) \\
\end{array}$ & $\begin{array}{c}4.77 \\
(2.40)\end{array}$ & $\begin{array}{c}3.55 \\
(2.11) \\
\end{array}$ \\
\hline $\begin{array}{l}\text { T6: [Apple untreated+ Trays treated } \\
\text { (Fungicide)] }\end{array}$ & $\begin{array}{c}2.26 \\
(1.80)\end{array}$ & $\begin{array}{c}4.08 \\
(2.25) \\
\end{array}$ & $\begin{array}{c}5.74 \\
(2.59) \\
\end{array}$ & $\begin{array}{c}5.84 \\
(2.61) \\
\end{array}$ & $\begin{array}{c}2.56 \\
(1.88)\end{array}$ & $\begin{array}{c}4.32 \\
(2.30) \\
\end{array}$ & $\begin{array}{c}5.95 \\
(2.63) \\
\end{array}$ & $\begin{array}{c}4.27 \\
(2.27) \\
\end{array}$ & $\begin{array}{c}2.41 \\
(1.84) \\
\end{array}$ & $\begin{array}{c}4.20 \\
(2.28) \\
\end{array}$ & $\begin{array}{c}5.84 \\
(2.61) \\
\end{array}$ & $\begin{array}{c}4.15 \\
(2.24) \\
\end{array}$ \\
\hline $\begin{array}{l}\text { T7: Apple Treatment with edible } \\
\text { wax }\end{array}$ & $\begin{array}{c}1.86 \\
(1.69) \\
\end{array}$ & $\begin{array}{c}3.19 \\
(2.04) \\
\end{array}$ & $\begin{array}{c}4.42 \\
(2.32)\end{array}$ & $\begin{array}{c}4.52 \\
(2.35) \\
\end{array}$ & $\begin{array}{c}2.21 \\
(1.79)\end{array}$ & $\begin{array}{c}3.67 \\
(2.16) \\
\end{array}$ & $\begin{array}{c}4.63 \\
(2.37) \\
\end{array}$ & $\begin{array}{c}3.50 \\
(2.10) \\
\end{array}$ & $\begin{array}{c}2.04 \\
(1.74) \\
\end{array}$ & $\begin{array}{c}3.43 \\
(2.10) \\
\end{array}$ & $\begin{array}{c}4.52 \\
(2.35) \\
\end{array}$ & $\begin{array}{c}3.33 \\
(2.06) \\
\end{array}$ \\
\hline T8: Treatment of wrappers with BF1 & $\begin{array}{c}2.48 \\
(1.86)\end{array}$ & $\begin{array}{c}4.34 \\
(2.31) \\
\end{array}$ & $\begin{array}{c}5.89 \\
(2.62) \\
\end{array}$ & $\begin{array}{c}6.02 \\
(2.64) \\
\end{array}$ & $\begin{array}{c}2.74 \\
(1.93)\end{array}$ & $\begin{array}{c}4.37 \\
(2.31) \\
\end{array}$ & $\begin{array}{c}6.15 \\
(2.67) \\
\end{array}$ & $\begin{array}{c}4.42 \\
(2.30) \\
\end{array}$ & $\begin{array}{c}2.61 \\
(1.90)\end{array}$ & $\begin{array}{c}4.36 \\
(2.31) \\
\end{array}$ & $\begin{array}{c}6.02 \\
(2.64) \\
\end{array}$ & $\begin{array}{c}4.33 \\
(2.28) \\
\end{array}$ \\
\hline T9: Treatment of wrappers with BF2 & $\begin{array}{c}2.35 \\
(1.83) \\
\end{array}$ & $\begin{array}{c}4.18 \\
(2.27) \\
\end{array}$ & $\begin{array}{c}5.82 \\
(2.61) \\
\end{array}$ & $\begin{array}{c}5.94 \\
(2.63) \\
\end{array}$ & $\begin{array}{c}2.63 \\
(1.90) \\
\end{array}$ & $\begin{array}{c}4.36 \\
(2.31) \\
\end{array}$ & $\begin{array}{c}6.05 \\
(2.65) \\
\end{array}$ & $\begin{array}{c}4.35 \\
(2.29) \\
\end{array}$ & $\begin{array}{c}2.49 \\
(1.87) \\
\end{array}$ & $\begin{array}{c}4.27 \\
(2.29) \\
\end{array}$ & $\begin{array}{c}5.94 \\
(2.63) \\
\end{array}$ & $\begin{array}{c}4.23 \\
(2.26) \\
\end{array}$ \\
\hline $\begin{array}{l}\text { T10: Treatment of wrappers with } \\
\text { fungicide }\end{array}$ & $\begin{array}{c}2.32 \\
(1.82) \\
\end{array}$ & $\begin{array}{c}4.16 \\
(2.27) \\
\end{array}$ & $\begin{array}{c}5.77 \\
(2.60) \\
\end{array}$ & $\begin{array}{r}5.90 \\
(2.62) \\
\end{array}$ & $\begin{array}{c}2.60 \\
(1.89) \\
\end{array}$ & $\begin{array}{c}4.36 \\
(2.31) \\
\end{array}$ & $\begin{array}{c}6.03 \\
(2.65) \\
\end{array}$ & $\begin{array}{c}4.33 \\
(2.28) \\
\end{array}$ & $\begin{array}{c}2.46 \\
(1.86) \\
\end{array}$ & $\begin{array}{c}4.26 \\
(2.29) \\
\end{array}$ & $\begin{array}{c}5.90 \\
(2.62) \\
\end{array}$ & $\begin{array}{c}4.21 \\
(2.26) \\
\end{array}$ \\
\hline T11: control & $\begin{array}{c}4.46 \\
(2.33) \\
\end{array}$ & $\begin{array}{c}7.53 \\
(2.92) \\
\end{array}$ & $\begin{array}{l}11.59 \\
(3.54) \\
\end{array}$ & $\begin{array}{c}11.98 \\
(3.60) \\
\end{array}$ & $\begin{array}{c}5.17 \\
(2.48) \\
\end{array}$ & $\begin{array}{c}7.92 \\
(2.98) \\
\end{array}$ & $\begin{array}{r}12.36 \\
(3.65) \\
\end{array}$ & $\begin{array}{c}8.48 \\
(3.04) \\
\end{array}$ & $\begin{array}{c}4.82 \\
(2.41) \\
\end{array}$ & $\begin{array}{c}7.73 \\
(2.95) \\
\end{array}$ & $\begin{array}{c}11.98 \\
(3.60) \\
\end{array}$ & $\begin{array}{c}8.17 \\
(2.98) \\
\end{array}$ \\
\hline Mean & $\begin{array}{c}2.42 \\
(1.84) \\
\end{array}$ & $\begin{array}{c}4.25 \\
(2.28) \\
\end{array}$ & $\begin{array}{c}5.94 \\
(2.61) \\
\end{array}$ & $\begin{array}{c}6.07 \\
(2.63) \\
\end{array}$ & $\begin{array}{c}2.73 \\
(1.92) \\
\end{array}$ & $\begin{array}{c}4.54 \\
(2.34) \\
\end{array}$ & $\begin{array}{c}6.19 \\
(2.66) \\
\end{array}$ & $\begin{array}{c}4.49 \\
(2.31) \\
\end{array}$ & $\begin{array}{c}2.58 \\
(1.88) \\
\end{array}$ & $\begin{array}{c}4.40 \\
(2.31) \\
\end{array}$ & $\begin{array}{c}6.07 \\
(2.63) \\
\end{array}$ & \\
\hline $\begin{array}{l}\text { * Figures in parentheses are square } \\
\text { Effect } \\
\text { Year } \\
\text { Storage interval } \\
\text { Treatment }\end{array}$ & $\begin{array}{c}\text { ot transf } \\
\text { CD } \\
0.01 \\
0.01 \\
0.01\end{array}$ & ned val & & & & & $\begin{array}{l}\text { fect } \\
\text { ear X St } \\
\text { ear X Tr } \\
\text { orage in }\end{array}$ & $\begin{array}{l}\text { interval } \\
\text { ent } \\
\text { X Treatı }\end{array}$ & & & & \\
\hline
\end{tabular}


Physiological weight loss was maximum in control $(11.98 \%)$ after 30 days of storage. Over all weight of fruits decreased in storage after 10, 20 and 30 days, higher rates of respiration during post-harvest rotting of fruits has been reported to result in physiological loss in weight which is accelerated by the high temperature (Ghafir $e t$ al., 2009). Infection of white rot also resulted in loss in weight of fruits after 30 days of storage in control. In the present study, all the treatments reduced the loss in weight of the fruit in the storage. However, minimum reduction in weight of fruits $(4.52 \%)$ was recorded in the fruits treated with edible wax followed by 4.77 and 4.87 per cent loss in fruits treated with Score and BF2, respectively in comparison to control after 30 days of storage. Post-harvest treatment of fruits with antifungal compounds like eugenol, thymol and menthol vapors is reported to reduce weight loss percentage in cherries and grapes (Serrano et al., 2005). Similarly, less reduction in physiological weight loss has been reported in strawberry fruits treated with cinnamon (Cinnamomum zeylanicum) and eucalyptus (Eucalyptus globulus) oil (Tzortzakis, 2007; Tian et al., 2011). Chauhan and Babu (2011) also reported that apple treated with leaf extract of Melia azedarach (20\%) proved to be most effective treatment in reducing physiological weight loss in apple fruits. Treatment of apple with neem based formulations proved effective in reducing the physiological weight loss of fruits and also reduced the growth of pathogens responsible for rotting (Singh et al., 2000).

\section{Statistical analysis}

The data recorded from various in vitro and laboratory experiments were subjected to statistical analysis. The differences exhibited by treatments in various experiments were tested for their significance at 5 per cent using standard procedure as described (Gomez and Gomez, 1983).

In conclusion positive impact of different treatments has been observed on quality parameters and shelf life of apple under storage condition. Various treatments i.e. fruit dip or impregnation of the packing material (trays or wrappers) with botanical formulations were found significantly effective in retaining the physiological weight loss, fruit TSS, titratable acidity and firmness of apple fruit under storage. Fruits treated with BF2 were also found equally effective in retaining fruit TSS, titratable acidity and fruit firmness after 30 days of storage. Treatment with BF2 was found effective as edible wax coating in minimizing the physiological weight loss during storage.

\section{Acknowledgement}

The authors are thankful to Head, Department of Plant Pathology, Dr. Y. S. Parmar University of Horticulture and Forestry, Nauni, Solan-173230 (HP), for providing necessary facilities during the experiment.

\section{References}

Ali, M.S., Raza, H., Khan, M.A. and Hussain, M. 2004. Effect of different periods of ambient storage on chemical composition of apple fruit. Int. J. Agri. Biol., 6: 568-571.

Anderson, W.H. 1956. Diseases of fruit crops. Mc Graw Hill Book Company, New York. $501 \mathrm{p}$.

Anonymous. 2012. National Horticulture Board (NHB) Statistical Database.

Barkai-Golan, R. and Phillips, D.J. 1991. Postharvest heat treatment of fresh fruits and vegetables for decay control. Plant Dis., 75: 1085-1089.

Bautista-Banos, S., Hernandez-Lopez, M., Bosquez-Molina, E. and Wilson, C.L. 2003. Effects of chitosan and plant extracts on growth of Colletotrichum gloeosporiodes anthracnose levels and quality of papaya 
fruit. Crop Protection, 22: 1087-1092.

Beaudry, R.M., Severson, R.F., Black, C.C. and Kays, S.J. 1989. Banana ripening: implications of changes in glycolytic intermediate concentrations, glycolytic and gluconeogenic carbon flux, and fructose 2, 6-bisphosphate concentration. J. Plant Physiol., 91: 1436-1444.

Ben, J. and Gaweda, M. 1985. Changes of pectic compounds in Jonathan apples under various storage conditions. Acta Physiologiae Plantarum, 7: 45-54.

Boyer, J. and Liu, R.H. 2004. Apple phytochemicals and their health benefits. Nutrition J., 3: 1-15.

Chauhan, S.K. and Babu, D.R. 2011. Use of botanicals: a new prospective for enhancing fruit quality over chemicals in an era of global climate change. Asian J. Environ. Sci., 6(1): 17-28.

Chauhan, S.K., Thakur, K.S., Dwivedi, S.K. and Bhanot, A. 2008. Storage behaviour of apple as affected by pre-and post-harvest treatments of neem based formulations, plant extracts and leaves. J. Food Sci. Technol., 45: 484-489.

Dhaliwal, G.S., and Arora, R. 1993. Changing status of insect pests and their management strategies. In: Gill K S, Dhaliwal G S and B $S$ Hansra (eds) Changing Scenario of Indian Agriculture. Commonwealth Publishers, New Delhi, 321- 344.

Ergun, M. and Satici, F. 2012. Use of Aloe vera gel as bio-preservative for Granny Smith and Red-Chief apples. The $J$. Animal and Plant Sci., 22(2): 363-368.

Ghafir, S.A.M., Gadalla, S.O., Murajei, B.N. and El-Nady, M.F. 2009. Physiological and anatomical comparison between four different apple cultivars under cold-storage conditions. African J. Plant Sci., 3: 133138.

Gomez, K.A. and Gomez, A.A. 1983. Statistical Procedures for Agricultural Research. $2^{\text {nd }}$ edition. John Willey and Sons Inc, New York, USA. 680 p.

Hussain, T. 2001. Food composition table for Pakistan. Islamabad: Govt. of Pakistan, Ministry of Planning and Development Division, Islamabad, Pakistan.

Ilyas, M.B., Ghazanfar, M.U., Khan, M.A., Khan,
C.A. and Bhatti, M.A.R. 2007. Post-harvest losses in apple and banana during transport and storage. Pak. J. Agri. Sci., 44(3): 534539.

Ismail, B.I., Haffar, R., Baalbaki, Y., Mechref and Henry, J. 2006. Physico-chemical characteristics and total quality of five date varieties grown in the United Arab Emirates. Int. J. Food Sci. Technol., 41(8): 919-926.

Jijakli, M.H. and Lepoivre, P. 2004. State of the art and challenges of post-harvest disease management in apples. Fruit and Vegetable Diseases-Volume 1, Mukerji K G (ed.), Kluwer Academic Publishers, Dordrecht, Netherlands, pp. 59-94.

Kahkonen, M.P., Hopia, A.I., Vuorela, H.J., Rauha, J.P., Pihlaja, K., Kujala, T.S. and Heinonen, M. 1999. Antioxidant activity of plant extracts containing phenolic compounds. J. Agri. Food Chem., 47: 39543962.

Knekt, P., Kumpulainen, J., Jarvinen, R., Rissanen, H., Heliovaara, M., Reunanen, A. and Aromaa, A. 2002. Flavonoid intake and risk of chronic diseases. American J. Clin. Nutri., 76: 560-568.

Konstantinou, S., Karaoglanidis, G.S., Bardas, G.A., Minas, S., Doukas E and Markoglou A.N. 2011. Post-harvest fruit rots of apple in Greece: pathogen incidence and relationships between fruit quality parameters, cultivar susceptibility and patulin production. Plant Dis., 95: 666-672.

Lu, Y. and Yeap, F.L. 2000. Antioxidant and radical scavenging activities of polyphenols from apple pomace. Food Chem., 68: 8185.

McCollum, T.G. 2002. Molecular biology of hostpathogen interactions in harvested horticultural crops. Hort Sci., 37(2): 456458.

Mueller, D.B., Koczwara, K., Mueller, A.S., Pallauf, J., Ziegler, A.G. and Bonifacio. E. 2009. Influence of early nutritional components on the development of murine autoimmune diabetes. Annals of Nutrition and Metabolism, 54: 208-217.

Raj, H. and Tomar, M. 2013. Use of aqueous and cow urine based plant extracts against postharvest diseases of apple. J. Mycol. Plant 
Pathol., 43 (2): 246-249.

Rivera, J. 2005. Cutting shape and storage temperature affect overall quality of fresh cut papaya cv. Maradol. J. Food Sci., 70(7): 488-489.

Serrano, M., Martinez, R.D., Castillo, S., Guillen, $F$ and Valero D. 2005. The use of the natural antifungal compounds improves the beneficial effect of MAP in sweet cherry storage. Innovative Food Sci. Emerging Technol., 6: 115-121.

Sesso, H., Gaziano, J.M., Liu, S. and Buring, J. 2003. Flavonoid intake and risk of cardiovascular disease in women. American J. Clin. Nutrition, 77: 1400-1408.

Shao, K., Kto, Y.Z., Zhao, L., Chen, Y.Y. and Chen, H. 2007. Wang effects of pre-storage heat treatment on fruit ripening and decay development in different apple cultivars $J$. Horticultural Sci. Biotechnol., 82: 297-303.

Shinde, G.S., Viradia, R.R., Patil, S.A. and Kakade, D.K. 2009. Effect of natural plant extracts and wrapping materials on storage behaviour of mango (Mangifera indica L.) cv. Kesar. Asian J. Horticulture, 4(1): 206210.

Singh, J.N., Acharya, P. and Singh, B.B. 2000. Effect of GA-3 and plant extracts on storage behaviour of mango (Mangifera indica) cv. Langra. Haryana $J$. Horticultural Sci., 29: 3-4.

Snowdon, A.L. 1990. Post-Harvest Diseases and Disorders of Fruits and Vegetables, Vol. 1.General introduction and fruits, CRC Press, Inc., Boca Raton, 302p.
Soliva, F.R.C. and Martin, B.O. 2003. Microbiological and biochemical changes in minimally processed fresh-cut Conference pears. European Food Res. Technol., 217: 4-9.

Spadaro, D., Garibaldi, A. and Gullino, M.L. 2004. Control of Penicillium expansum and Botrytis cinerea on apple combining a biocontrol agent with hot water dipping and acibenzolar-s-methyl, baking soda, or ethanol application. Postharvest Biol. Technol., 33(2): 141-151.

Tian, J., Ban, X.Q., Zeng, H., He, J.S., Huang, B. and Wang, Y.W. 2011. Chemical composition and antifungal activity of essential oil from Cicuta virosa L. var. latisecta Celak. Int. J. Food Microbiol., 145: 464-470.

Tzortzakis, N.G. 2007. Maintaining postharvest quality of fresh produce with volatile compounds. Innovative Food Sci. Emerging Technol., 8: 111-116.

Vieira, F.G.K., Borges, G.D.C., Copetti, C., Amboni, R.D.M.C., Denardi, F. and Fett, R. 2009. Physico-chemical and antioxidant properties of six apple cultivars (Malus domestica Borkh) grown in southern Brazil. Scientia Horticulturae, 122: 421-425.

Wijewardane, R.M.N.A. and Guleria, S.P.S. 2009. Combined Effects of Pre-cooling, application of natural extracts and packaging on the storage quality of apple (Malus domestica) cv. Royal Delicious. Trop. Agri. Res., 21(1): 10-20.

\section{How to cite this article:}

Kishor Sharma and Harender Raj. 2017. Efficacy of Local Bioresources and Chemical Treatment against Quality Parameters of White Rot Inoculated Apple Fruits. Int.J.Curr.Microbiol.App.Sci. 6(4): 1838-1850. doi: https://doi.org/10.20546/ijcmas.2017.604.219 